Vol. 44, N. 3 : pp. 319 - 324, September, 2001 ISSN 1516-8913 Printed in Brazil

\title{
Habitat Selection by Fish in an Artificial Reef in Ilha Grande Bay, Brazil
}

\author{
Daniel Shimada Brotto ${ }^{1}$ and Francisco Gerson Araujo ${ }^{2 *}$ \\ ${ }^{1}$ Universidade Veiga de Almeida, Depto. Ciências da Saúde, rua Ibituruna, 108, CEP. 20271-020, Rio de Janeiro - RJ, \\ Brazil; ${ }^{2}$ Universidade Federal Rural do Rio de Janeiro, Laboratório de Ecologia de Peixes, km 47 - Antiga Rodovia Rio - São \\ Paulo, Seropédica - RJ, Brazil
}

\begin{abstract}
The use of artificial structures as a shelter for fishes was evaluated aiming to assess increase in fish abundance in

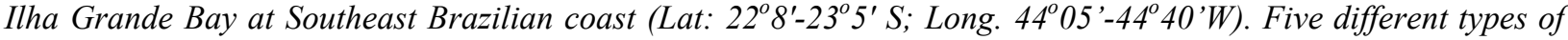
structures, made of clay tiles, with an increase range on size and complexity were tested to assess their efficiency. Fish were counted in each type of structure from May-1996 to April-1997 by underwater observation made with snorkelling. According to the pattern of concentration in the structures, two groups of fishes were identified. One comprised by E. guaza, M. rubra, R. randalli, S. hispidus, Sphoeroides sp and Haemulun sp showed affinity for hard bottom, irregular profile and an increase in abundance on the more complex and biggest structures. The other comprised by Chylomicterus sp, Gerres spp, Anchoa sp, Diapterus sp, Oligoplites sp and D. radiale did not present clear preference for hard bottom.
\end{abstract}

Key words: Artificial Reefs, Brazil, Fish, Habitat selection

\section{INTRODUCTION}

Coastal zones rank among the most endangered marine ecosystems. Artificial reefs, which consist of submerse structures showing an ample variety of form, materials and compositions, were though to be a possible solutions for this problem. In the last three decades several authors have been working on this area as Carslile et al. (1964), Davis (1985), Yokouchi et al. (1991) and Ambrose (1994).

In Brazil the avaiable literature on this subject is limited to reports and meeting proceedings, hence formal scientific information is still lacking. A year round project for assessing patterns of habitat colonisation by fish species on different types of structures was developed in Ilha Grande Bay (Latitude: $22^{\circ} 8^{\prime}-23^{\circ} 5^{\prime}$ ), at Rio de Janeiro State, Brazil (Figure 1).
The aim of the present work was to test different forms and complexity of low costing artificial reefs to evaluate their use as shelters by fish.

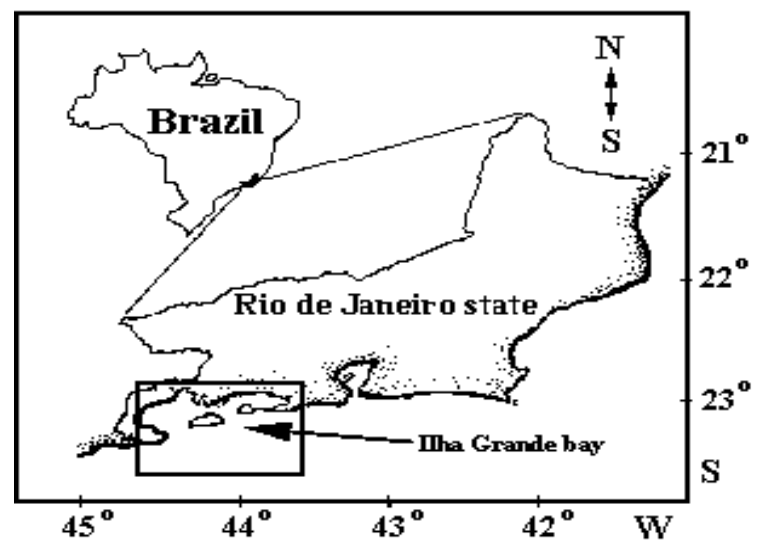

Figure 1 - Geographical localisation of Ilha Grande Bay.

* Author for correspondence 


\section{MATERIALS AND METHODS}

Five types of structures made of $41 \times 22 \mathrm{~cm}$ baked clay tiles were arranged in an increasing complexity pattern using one, three, six, nine and twelve tiles in each type, with five replications each (Figure 2). These structures and five control sites (no tile) were deployed randomly along five parallel rows on sandy bottom, at 1,5 to 2 meters deep, about $10 \mathrm{~m}$ away from the shoreline.

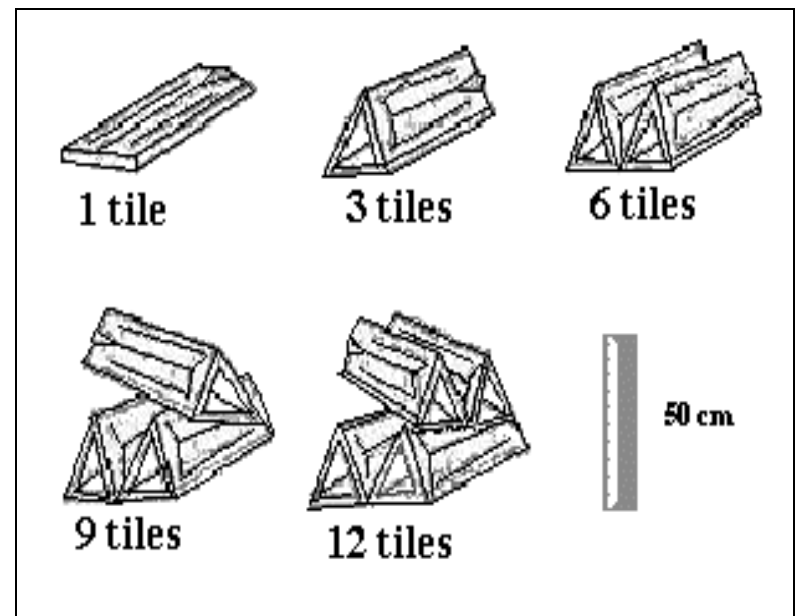

Figure 2 - Schematic draw of the types of structures.

From May 1996 to April 1997, a total of 46 weekly surveys of underwater observations made by snorkelling were performed in each structure. In each survey all the 25 structures and the 5 control sites were inspected. A plastic sheet was used for recording overall fish abundance.

Only the fishes that occurred in more than 10 percent of the total number of surveys (frequency of occurrence - FO >10\%), were considered in the analysis, with FO calculated as follow:

$$
\mathrm{FO}=\frac{\text { (number of oocurrences of the fish } \times 100 \text { ) }}{\text { number of obsenations }}
$$

The abundance of fish among the different types of structures were compared by Kruskal-Wallis analysis, in order to identify possible affinities for a certain type of structure.

\section{RESULTS}

Twenty fish species were recorded, comprising 22 genera and 22 families. Haemulon spp were constant in almost all sampling $(\mathrm{FO}=98)$ and showed the second highest contribution to the total abundance of fish, amounting 25\% of all fish. Juvenile Gerres spp were the most abundant fish group, amounting $51.2 \%$ of all fish counted and presenting FO $=81,6$. Sphoeroides sp were also high frequent in the sampling although with low contribution in total abundance (Table 1).

Table 1 - Frequency of occurrence, total and percentual abundance of fish.

\begin{tabular}{|c|c|c|c|}
\hline SPECIES & $\mathrm{FO}$ & TOTAL & $\%$ \\
\hline Haemulon spp. & 98,0 & 1114 & 25,0 \\
\hline Sphoeroides sp. & 89,8 & 115 & 2.6 \\
\hline Gurres spp. & 81,6 & 2278 & 51,2 \\
\hline Micteroperca rubra & 61,2 & 78 & 1,8 \\
\hline Diplectrum radiale & 59,2 & 68 & 1.5 \\
\hline Scorpaena sp. & 44,9 & 28 & 0,6 \\
\hline Stephamolepis hispidus & 30,6 & 29 & 0,7 \\
\hline Serroms flaviventris & 30,6 & 20 & 0,4 \\
\hline Chylomictertus sp. & 30,6 & 18 & 0,4 \\
\hline Oligoplites sp. & 24,5 & 22 & 0,5 \\
\hline Ripticis randalli & 18,4 & 10 & 0,2 \\
\hline Díaprerus sp. & 14,3 & 15 & 0.3 \\
\hline Epinephehus guaza & 12,2 & 16 & 0.4 \\
\hline Anchoa sp. & 10,2 & 420 & 9,4 \\
\hline Diplodius argenteus & 8,2 & 4 & 0,1 \\
\hline Sinodius foetens & 6,1 & 3 & 0,1 \\
\hline Lutjanns sinagris & 6,1 & 3 & 0,1 \\
\hline Harengula clupleola & 4,1 & 121 & 2,7 \\
\hline Mugl/ sp. & 4,1 & 35 & 0.8 \\
\hline Dactylopferus yolitapis & 4,1 & 3 & 0,1 \\
\hline Alherina brasilliensis & 2,0 & 50 & 1,1 \\
\hline Fistularia sp. & 2,0 & 1 & $<0.1$ \\
\hline TOTAL & 100 & 4451 & 100 \\
\hline
\end{tabular}

According to each kind of structure, different patterns of abundance were observed for each fish group, and these patterns seemed to be related to habitat requirements of such fishes.

The serranids E. guaza, M. rubra, R. randalli, haemulidae Haemulun sp, monacantid $S$ hispidus, tetraodontiforms Sphoeroides sp and Chylomicterus sp showed direct relationship between their abundance and structure dimensions, as well as for the area of available for colonisation by bentos (Figure 3). 


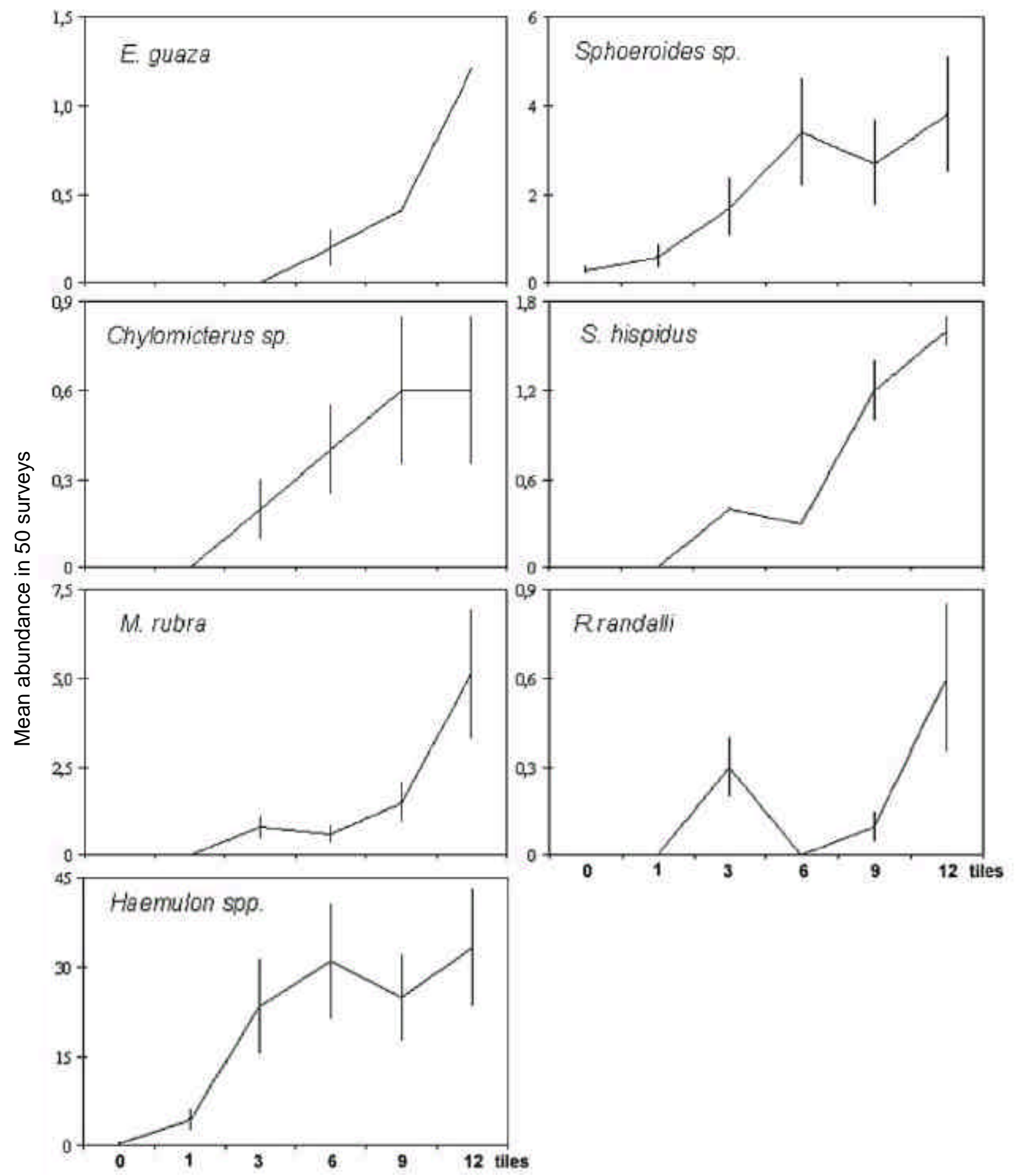

Figure 3 - Mean abundance of analysed fish species that presented increasing pattern by type of structure.

On the other hand, no clear association was observed between the complexity and dimensions of structures and abundance of Scorpaena sp, Gerres spp, Diapterus sp, Anchoa sp,
S. flaviventris, Oligoplites sp. Furthermore, D. radiale seemed to occur in higher abundance in simpler structures (Figure 4). 

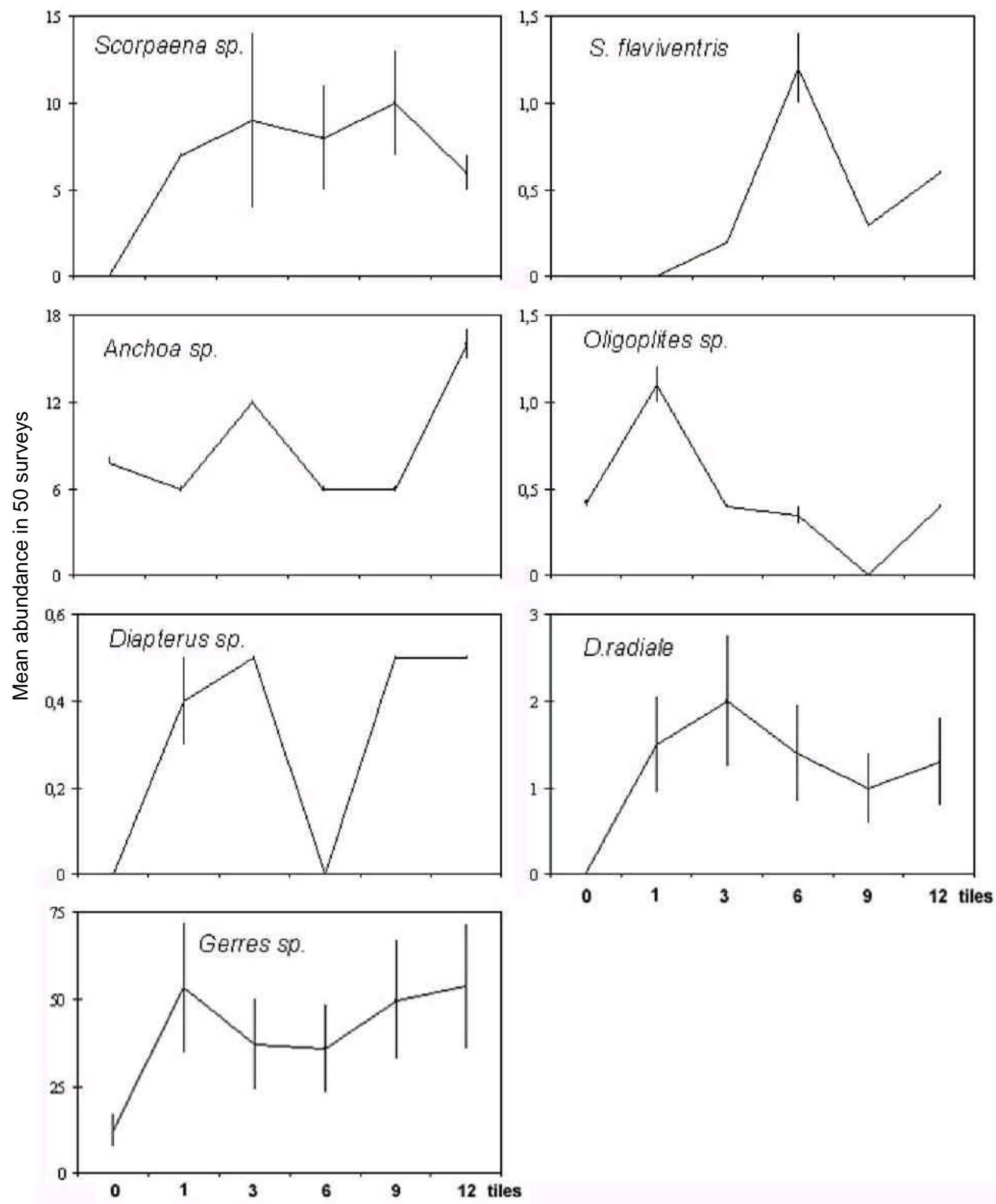

Figure 4 - Mean abundance of analysed fish species that presented no increasing pattern by type of structure

The Kruskal-Wallis analysis showed that there were significant differences among almost all fish species abundance analysed by type of structure (Table 2). 
Table 2 - Values of $\mathrm{X}^{2}$ and significance of the difference among fish abundance among types of structures.

\begin{tabular}{llc}
\hline Fish Species & $\mathrm{X}^{2}$ & Significance \\
Sphoeroides $s p$ & 51,0 & $\mathrm{~ns}$ \\
Chylomicterus $s p$ & 12,8 & $*$ \\
M. rubra & 69,9 & $* *$ \\
R. randalli & 15,8 & $* *$ \\
Gerres spp & 31,9 & $* *$ \\
Diapterus $s p$ & 5,7 & $\mathrm{~ns}$ \\
Haemulon $s p$ & 146,9 & $* *$ \\
E. guaza & 26,9 & $* *$ \\
Oligoplites $s p$ & 26,9 & $*$ \\
Scorpaena $s p$ & 10,4 & $*$ \\
S. flaviventris & 23,5 & $* *$ \\
D. radiale & 17,3 & $* *$ \\
S. hispidus & 36,7 & $* *$ \\
Anchoa $s p$ & 2,0 & $\mathrm{~ns}$ \\
\hline
\end{tabular}

ns $=$ non significant, $*=0,01<\mathrm{p}<0,05, * *=\mathrm{p}<0,01$

An attempt to adapt the patterns presented, by the surveyed fish species in this work to the classification of Ogawa (1982) for fishes associated to artificial reefs is presented in Table 3.

Table 3 - Types of fish (Ogawa, 1982), pattern, and observed species.

\begin{tabular}{|c|c|c|}
\hline Type & Pattems & Observed species \\
\hline A - & $\begin{array}{l}\text { Pelagic and epipelagic fish } \\
\text { that hovers near the reef areal }\end{array}$ & $\begin{array}{l}\text { Anchoo sp, } \\
\text { Oligoplites sp. }\end{array}$ \\
\hline B - & $\begin{array}{l}\text { Demersal fish that swims } \\
\text { near the reef without } \\
\text { touching it for long periods of } \\
\text { time }\end{array}$ & $\begin{array}{l}\text { Gerres spp. } \\
\text { Haemulon spp } \\
\text { Diopterus sp } \\
\text { Sphoeroides sp. } \\
\text { Chylomicterus sp. } \\
\text { S hispidus. }\end{array}$ \\
\hline C - & $\begin{array}{l}\text { Demersal fish that keeps a } \\
\text { steady position touching the } \\
\text { reef or the bottom near the } \\
\text { reof for considerable periods } \\
\text { of time }\end{array}$ & $\begin{array}{l}\text { 14. nuhra, } \\
\text { D. radiale, } \\
\text { Scorpaena sp. } \\
\text { E. guaza. } \\
\text { S. Jlaviventris } \\
\text { R. randall }\end{array}$ \\
\hline
\end{tabular}

\section{DISCUSSION}

The majority of serranids presented higher abundance in the bigger and more complex type of structure, as this group comprised by predators that sought shelter in cavities and rock outcrops (Hobson 1965, 1972; Collete \& Talbot 1972). Beets \& Hixon (1994) also observed higher abundance of serranids in artificial reefs structure provided by high number of cavities.
S. hispidus and Chylomicterus sp presented higher abundance related to the bigger structures as they preyed mainly on invertebrates that occurred on hard bottoms. The unclear pattern observed for $S$. flaviventris was probably related to the small size of this species that imposed few spatial requirements. For $D$. radiale the higher abundance observed in smaller structures could be related to a diet based on soft bottom organisms or competition with other serranids.

Fishes of the genus Haemulon spp, Gerres spp, Sphoeroides sp and Scorpaena sp, presented different patterns of abundance among structure. For this groups, affinity for hard bottoms of irregular profile was not evident, as they didn't show significant differences in abundance, according to increasing structure complexity. Perhaps as suggested by Patton et al. (1985), in some cases, a homogeneous scattering of structures in an ample area would show better results than pilling these structures.

This experiment has shown that the deployment, colonisation and monitoring of an artificial reef is something more complex than just throwing outboard any kind of scrap without proper planning and study, claiming to increase in fish productivity.

In Brazil, artificial reefs are often considered as tools for fish concentration aiming to help fisheries, rather than an option for environmental restoration.

Deployment of artificial reefs only for fisheries and political purposes without planning and a comprehensive monitoring program tends only to increase the deterioration. Artificial reefs as barriers to prevent trawling for shrimp, could probably lead to increase in populations of hard bottom fishes that prey on shrimp. Also the use of artificial reef just as fish aggregation devices for fisheries purposes could not be understood as a long term solution for marine living resources depletion. In this situation, the most appropriate solution could be certainly related to programs of restoration, patrolling and also of environmental education. Priority must be given to programs where artificial reefs are truly understood as a recovering measure from land reclamation and other kind of alteration in the coastal systems, coupled with research accompanying initiatives to assess their influence in these environments. 


\section{RESUMO}

$\mathrm{O}$ uso de estruturas artificiais como abrigos por peixes, foi avaliado objetivando o incremento da abundância de peixes na baía da Ilha Grande na costa da região sudeste brasileira. Cinco diferentes tipos de estruturas, feitas de telhas de barro, de crescentes tamanhos e complexidades foram testadas para avaliar sua eficiência como abrigos de peixes. Os peixes associados a cada tipo de estrutura foram contados, semanalmente de maio/1996 a abril/1997, através de observações subaquáticas realizadas por mergulho livre. De acordo com os padrões de abundância, dois grupos de peixes foram identificados. O primeiro formado por E. guaza, Chylomicterus sp, Sphoeroides sp M. rubra, $R$. randalli, $S$. hispidus, e Haemulun $\mathrm{sp}$ apresentou afinidade por fundos duros de relevo irregular cuja abundância proporcional ao tamanho e complexidade das estruturas, e o outro formado por S. Flaviventris, Scorpaena sp, Diapterus sp, Gerres spp, Anchoa sp, Oligoplites sp, e $D$. radiale que não apresentou ocorrência associada com as estruturas.

\section{REFERENCES}

Ambrose, R. F. (1994), Mitigating the effects of a coastal power plant on kelp forest community: rationale and requirements for na artificial reef. Bull. Mar. Sci.. 55, 694-708
Beets, J. and Hixon, M. A. (1994), Distribution, persistence, and growth of groupers (Pisces: Serranidae) on artificial and natural patch reefs int the Virgin islands Bull. Mar. Sci. 55, 470-483

Carlisle Jr, J. G.; Turner, C. H. and Ebert, E. E. (1964), Artificial habitat in the marine environment. Fish. Bull. (124) The resour. agen. of Calif., Dept of Fish and Game, 93p

Collette, B. B. and Talbot, F. H. (1972), Activity patterns of coral reef fishes with emphasis on nocturnal-diurnal changeover. Bull. Natur. Hist. Mus. of Los Ang. County. 14, 98-178

Hobson, E. S. (1965), Diurnal - nocturnal activity of some inshore fishes in the Gulf of California. Copeia, 3, 291-302

Hobson, E. S. (1972), Activity of Hawaiian reef fishes during the evening and morning transitions between daylight and darkness. Fish. Bull. 70 (3), 715-740

Ogawa, Y. (1982), Jinko giosho, tsukiiso, and marine organisms. In Vik, S.F.(ed.), Japanese artificial reef technology. Aquabio, Inc., 2957 Sunset Blvd., Bellair Bluffs, Fl. Technical Report 604p

Patton, M. L.; Grove, R. S. and Harman R. F. (1985), What do natural reefs tell us about designing artificial reefs in southern California. Bull. Mar. Sci. 37, 279-298

Yokouchi, H.; Yamamoto, R. and Ishizaki, Y. (1991), Construction of artificial seaweed bed accompanied with the land reclamation for unit no 3 of Ikata Power Station. Marine Pollution Bulletin 23, 719-722 